اثرات ماده آلى محلول بر جذب علفكش سيمازين در خاكهاى مختلف

محمدرضا ريكى 1*

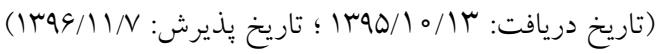

جكيده

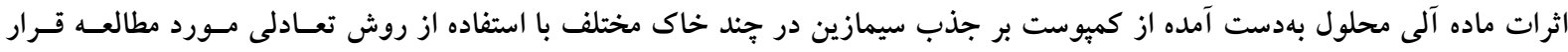

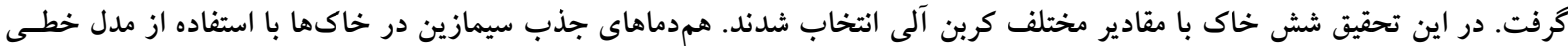

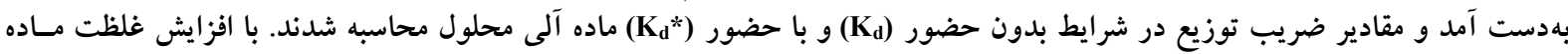
آلى محلول در دامنه ه0-ه ميلى

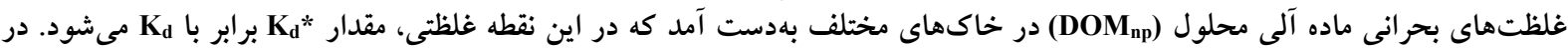

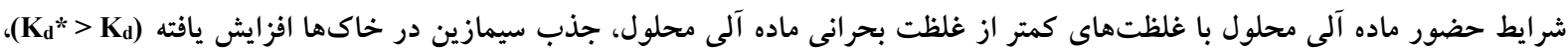

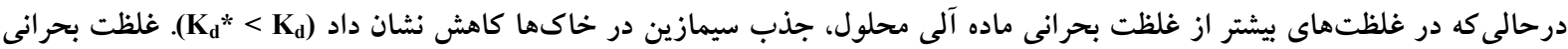

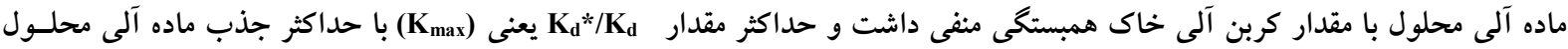

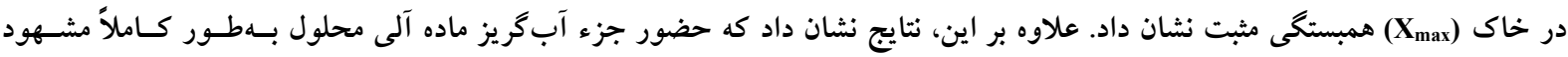

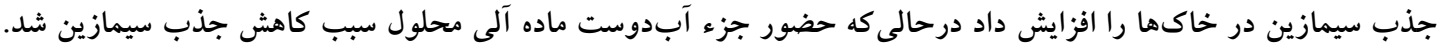

وازههاى كليدى: آفت كش، سيمازين، ماده آلى محلول، جذب، خاى

ا. گروه توليدات گياهى، دانشكده كشاورزى، مجتمع آموزش عالى سراوان، سراوان

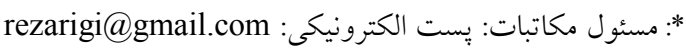




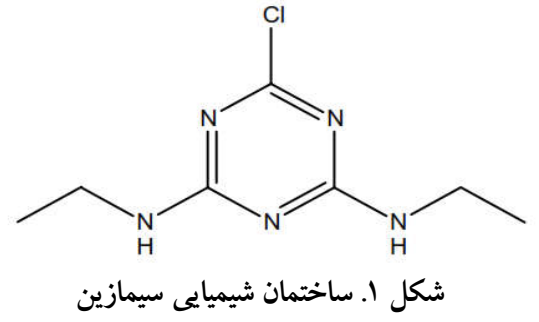

(6-chloro- $N, N$ '-diethyl-1,3,5-triazine-2,4-diamine) (Simazine) علفكشى از خانو اده اس - تريـازين (s-Triazine) اسـت (شـكل

علفكش سـيمازين بـه فرمـول مولكسولى

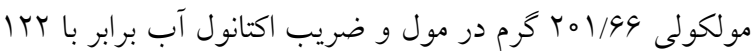
و حلاليت كمى در آب بلهميزان ه ميلى گرم در ليتـر در مب درجسه

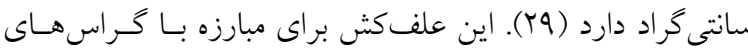
يكساله و تعداد زيادى از يهنبر گها در كشت زراعى و باغـات

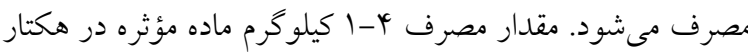

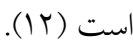

تمايل جذبى علفكث با افزايش ميـزان مـاده آلى، افـزايش

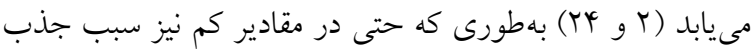

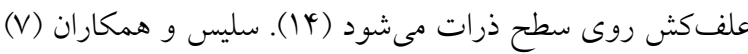

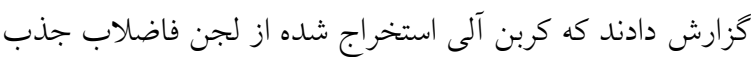

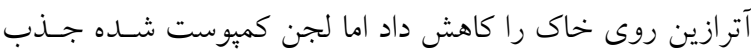

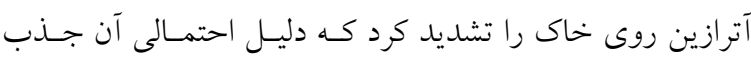

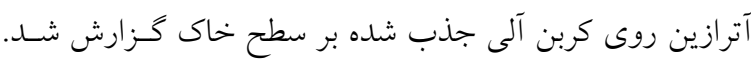

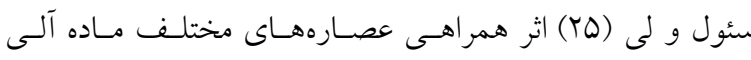

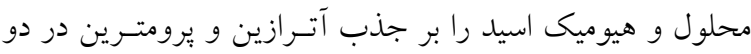

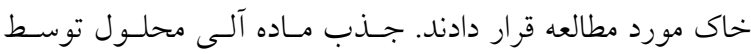

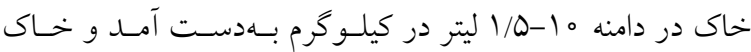

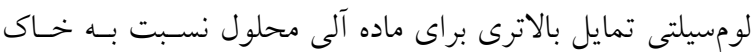

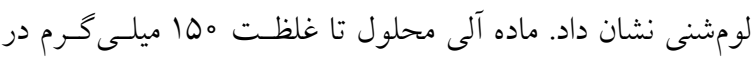

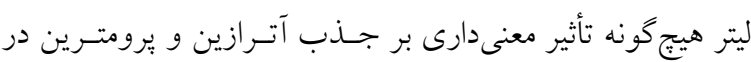
خاكها نداشت. جن و همكاران (9) با بررسى اثر اجـزاى مـاده

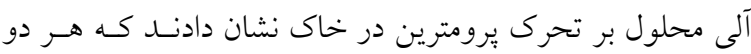

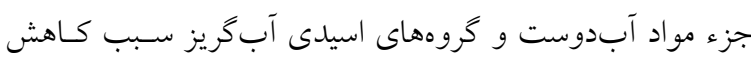

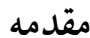

سرنوشت آفتكشهاى موجود در خاى تحت تـأثير فراينـدهاى فيزيكى و شيميايى مختلفى است. جذب مهمترين فرايند بوده كه ساير فرايندها از قبيل تحرك، بايدارى و تجزيـه را تحـت كتتـرل

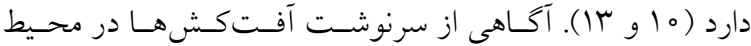

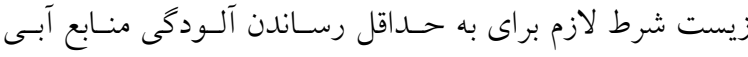

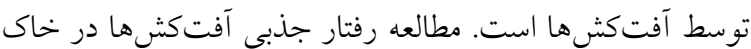
در ارتباط با برقرارى ييوند بين آفتكش با ذرات رس و مواد آلى

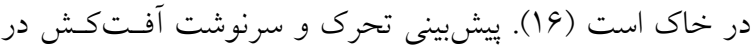
خاكها، راهكار مناسبى براى شناسايى و كاهش اثرات مضر آنها

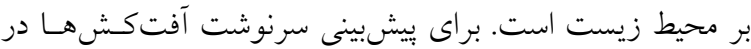

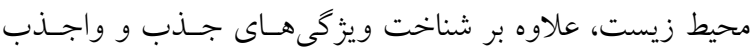
آنها در خاك، بارامترهاى فيزيكوشيميايى مختلف يكى تركيب مثل

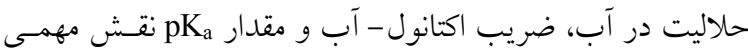

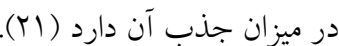
مواد اصلاح كننده آلى غيرمحلول در خـاكهـا، بـهــور قابـل ملاحظهاى جذب آلايندهــاى آلى خـاكهــا را تشـديد مسى كنــــ

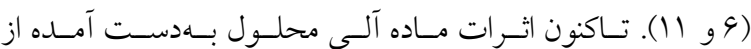

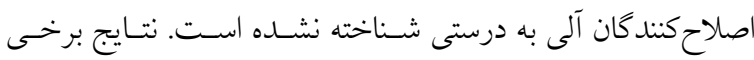

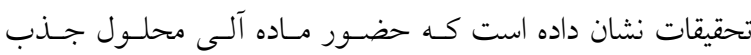

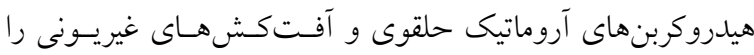

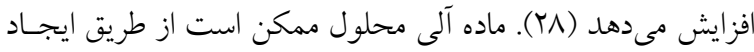

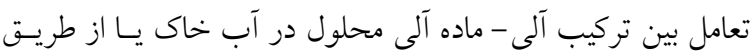

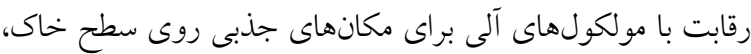

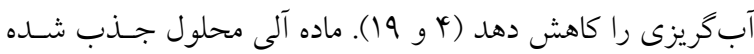

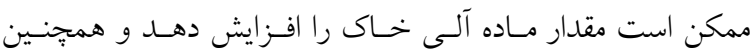

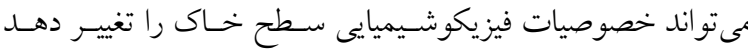

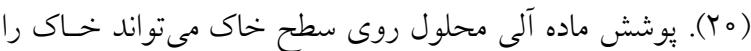
قادر به جذب تركيبات آلى بيشترى كند (Y). تفاوت خصوصسيات

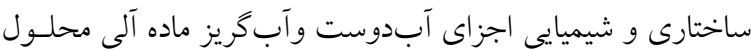
سبب بروز اختلاف در قابليـت بييونــــــيــات آلى و رفتارهـاى

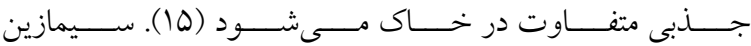




\begin{tabular}{|c|c|c|c|c|c|c|}
\hline \multicolumn{7}{|c|}{ جدول 1. ويزگى هاى فيزيكى و شيميايى خاكهاى مورد مطالعه } \\
\hline سيلت & شن & رس & ماده آلى & \multirow{2}{*}{$\mathrm{pH}$} & كلاس & \multirow{2}{*}{ 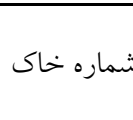 } \\
\hline \multicolumn{4}{|c|}{$(\%)$} & & بافت خاى & \\
\hline$r q / N T$ & $19 / \pi 4$ & $K r / q 4$ & T/09 & VNA & رس سيلتى & 1 \\
\hline MINT & $r \Delta / \mu Y$ & rT/QY & $|/ 4|$ & V/GY & لوم رسى & r \\
\hline$M T / N T$ & $r q / \mu_{Y}$ & rq/94 & $1 / \pi$ & $\mathrm{V} N \mathrm{r}$ & لوم & r \\
\hline rANT & rT/MY & TN/QY & $\circ / 9 V$ & VrG & 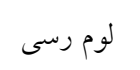 & $r$ \\
\hline$r r / N T$ & $\Delta \psi / N Y$ & IV/aY & $\circ / N$ & $V / Q Y$ & لوم شنى & 0 \\
\hline rG/NT & $0 . \mu r$ & IT/AY & $0 / 49$ & $V / 4 \circ$ & لوم & 9 \\
\hline
\end{tabular}

نظير مقدار رس و كربن آلى تفاوت داشته باشند (جدول ().

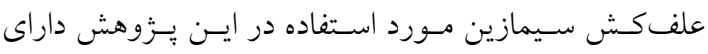

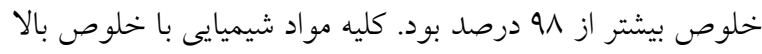

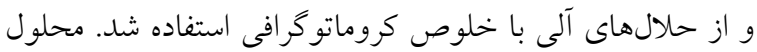

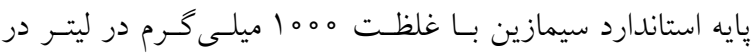

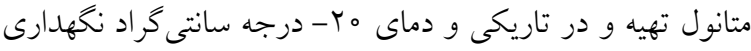

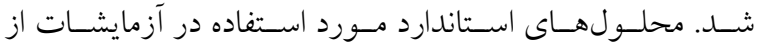

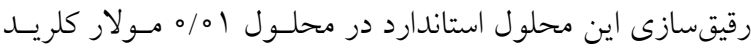
كلسيم تهيه شدند.

نمونه كميوست بهعنو ان منبع ماده آلى محلول مـورد استفاده

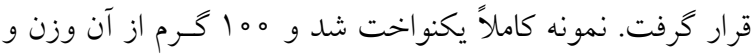

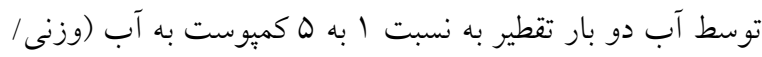

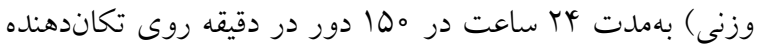

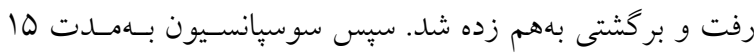

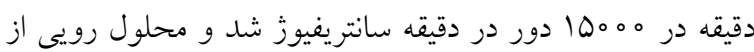

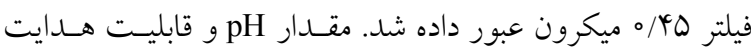

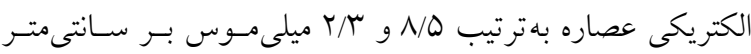

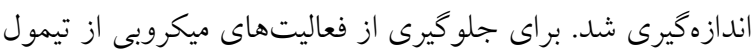

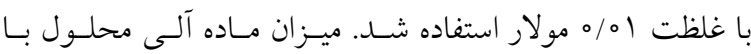

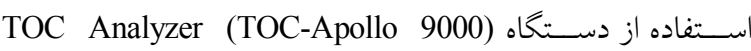

$$
\text { اندازهكيرى شد. }
$$

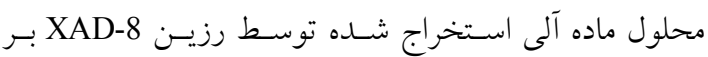

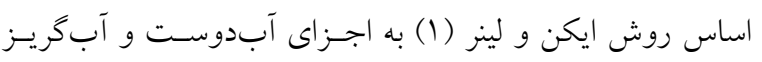

جذب برومترين در خاكها شدند و تحرك آن را افزايش دادنـــ.

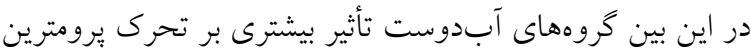
داشتند. تاكنون مطالعه محـدودى بــراى بررسى جـــب سـيمازين و

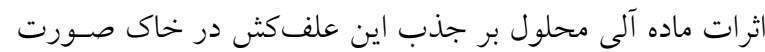

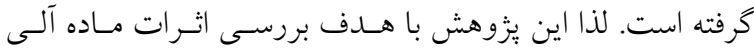

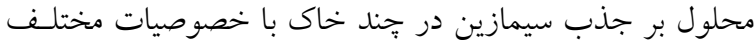

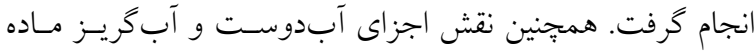

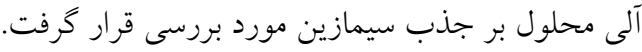

\section{مواد و روشها - (- ماد}

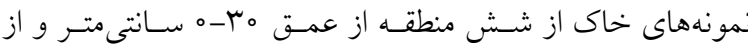
مكانهايى كه تحت تيمار سيمازين نبوده، نمونهبردارى شدند. بـهـ

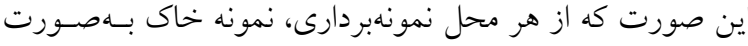
مركب، از اراضى كشاورزى بهطور تصادفى برداشـت شـد. بــراى

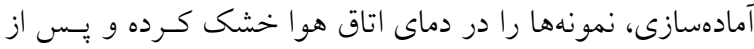
كوبيدن و عبور از الك دو ميلىمتـرى در كيسههـاى بلاسـتيكى ريخته و تا زمان مصرف در دماى \&ٔ درجه سانتى كـراد نخهـدارى

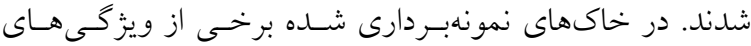

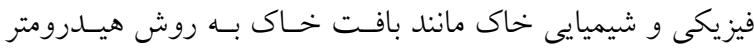

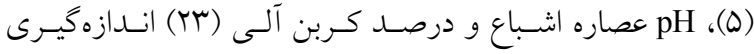

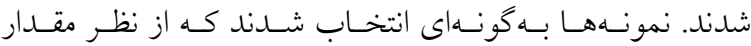
ويزگگ هاى فيزيكى و شيميايى مؤثر در جذب سطحى آفتكشها 
غلظتهاى ماده آلى محلول، در محلول 101

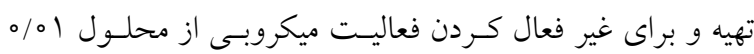

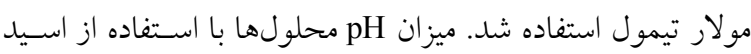

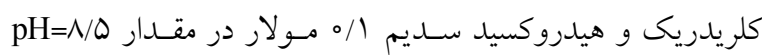

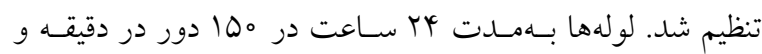
دماى

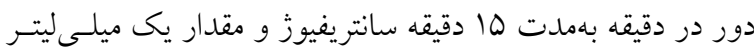

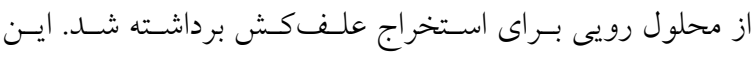

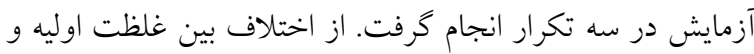

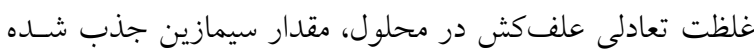

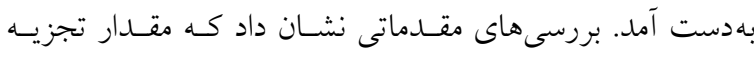
فتوشيميايى، تصعيد و جذب روى لوله ناجيز است.

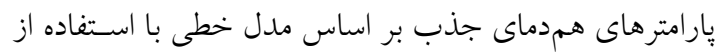
رابطه (1) براى سيمازين محاسبه شد:

$\mathrm{X} / \mathrm{M}=\mathrm{K}_{\mathrm{d}} \times \mathrm{C}$

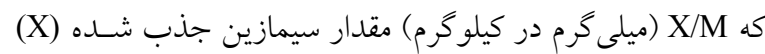

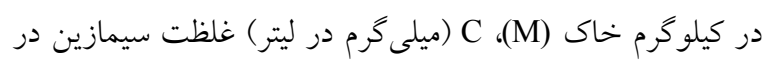

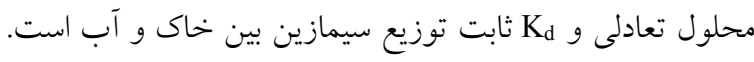

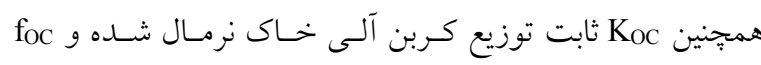
مقدار كربن آلى خاك است (Y). بنابراين:

$\mathrm{K}_{\mathrm{OC}}=\mathrm{K}_{\mathrm{d}} \times 100 / \mathrm{f}_{\mathrm{OC}}$

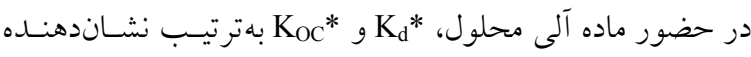
ثابت توزيع ظاهرى و ثابت توزيع ظاهرى كربن آلى نرمال شــده،

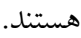

\section{نتايج و بحث}

\section{جذب ماده آلى محلول در خاكها}

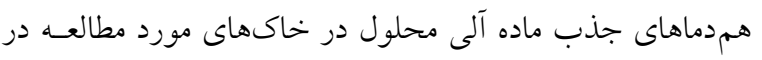

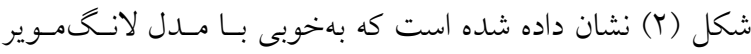
مطابقت داشت. با افزايش غلظت ماده آلى محلول، جـــب آن آن درد

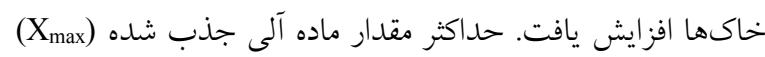

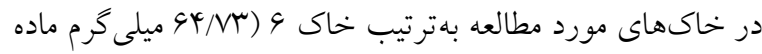

جداسازى شد. محلول اسيدى شده ماده آلى (با ب= pH) با شدت

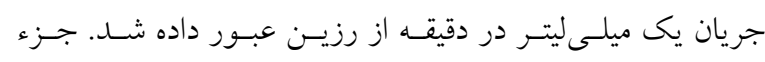

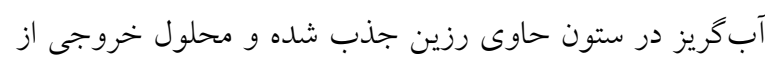

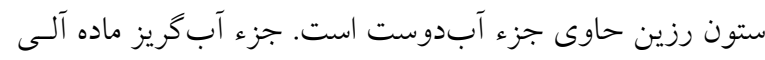

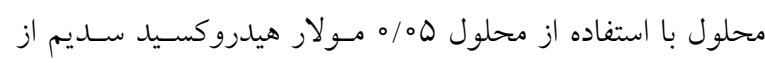

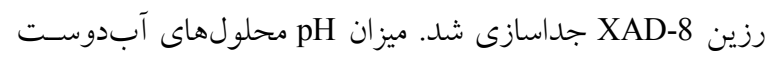

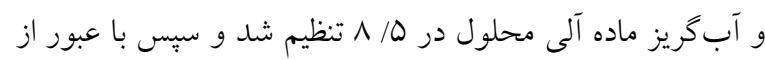

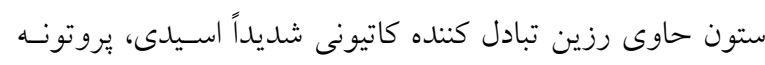

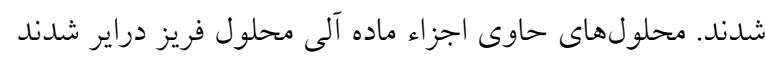

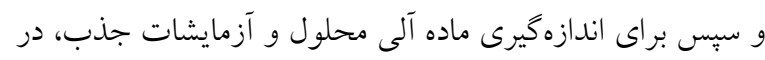

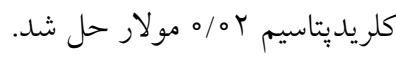

آزمايشات جذب ماده آلى محلول در خاكها

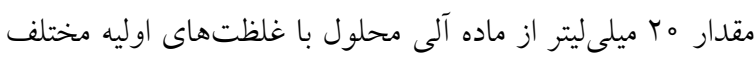

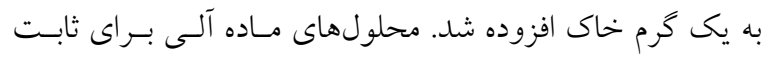

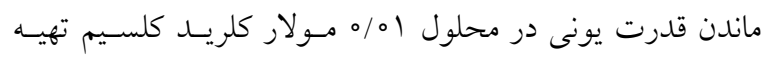

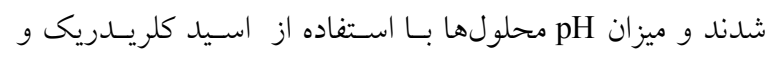

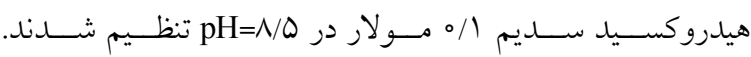

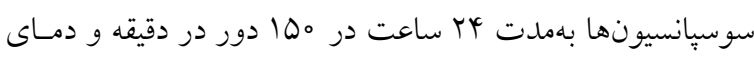

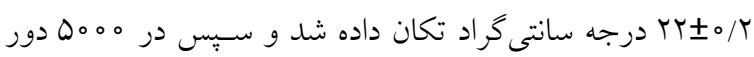

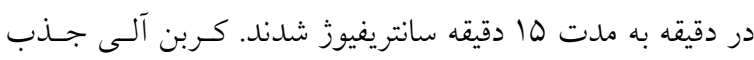
شده از اختلاف بين غلظت اوليه و تعادلى مقدار كربن آلى در هر

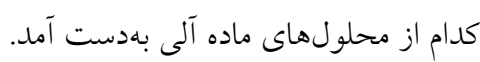

جذب سيمازين در حضور ماده آلى محلول در خاكها

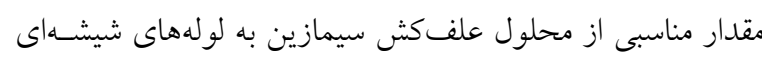

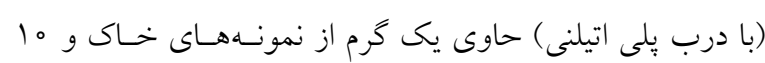

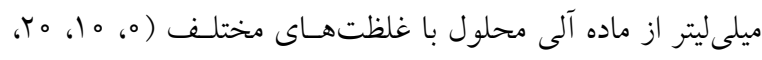

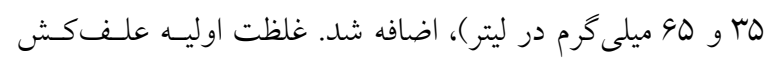

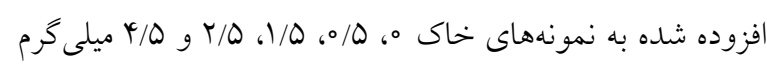

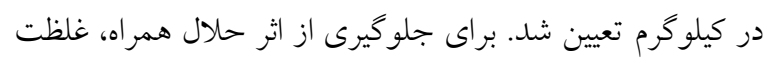

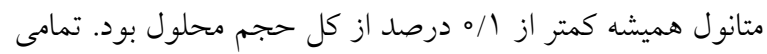




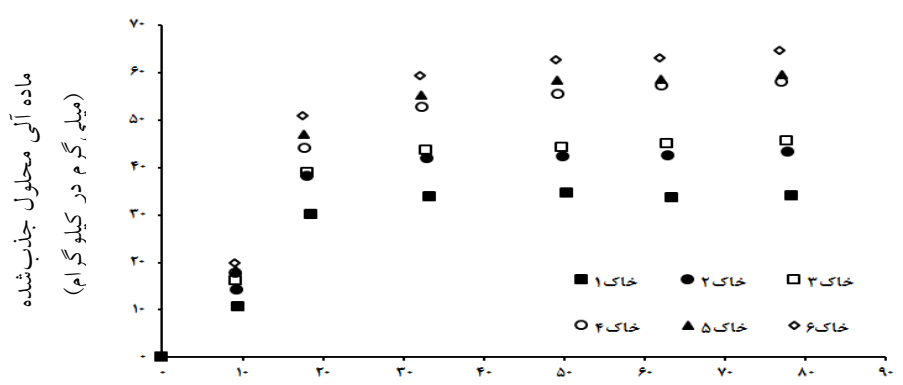

ماده محلول (ميلى گرم در ليتر)

شكل r. همدماهاى لانگموير براى جذب ماده آلى محلول در شش خاك مورد مطالعه

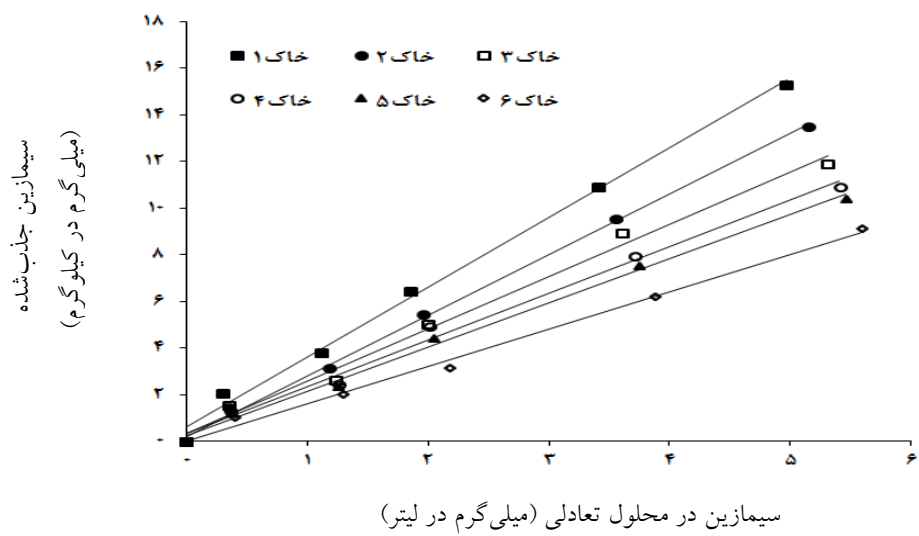

شكل r. همدماهاى خطى جذب علف كث سيمازين در شش خاك مورد مرد مطالعه

اين سطوح جذبى در خاكهاى با ماده آلى بيشتر، بهعلت اشـغال

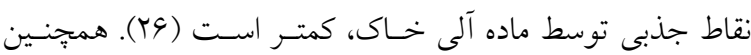

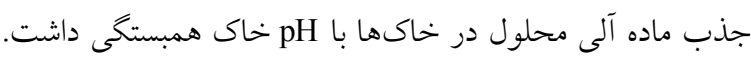

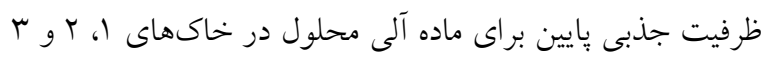

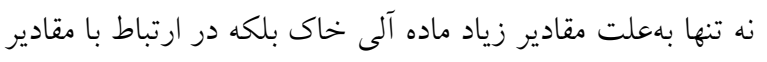

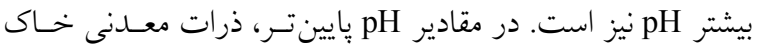

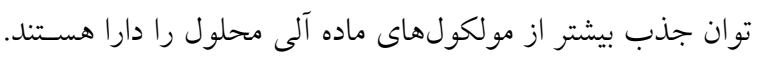

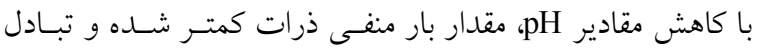

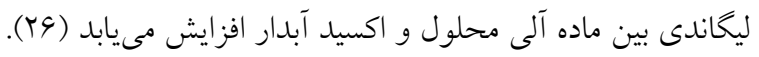

جذب سيمازين در خاكها شكل (T) جذب سيمازين را در شش خاك مـورد مطالعـه نشـان

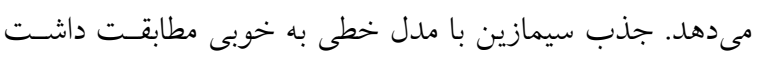

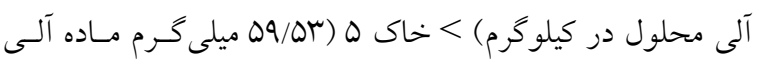

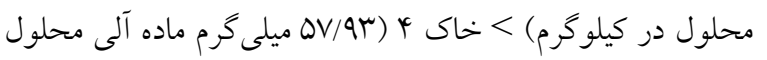

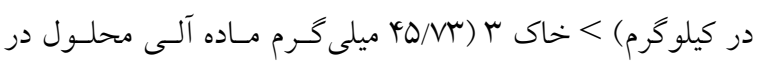

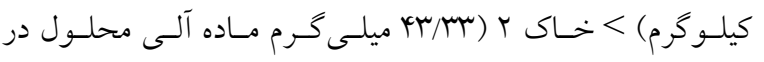

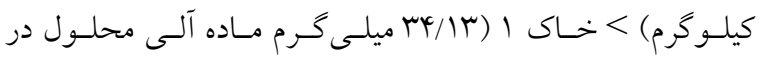

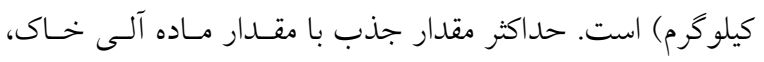

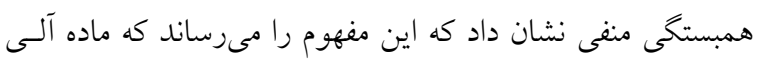

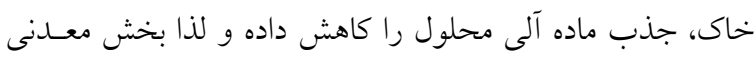

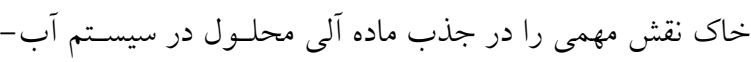

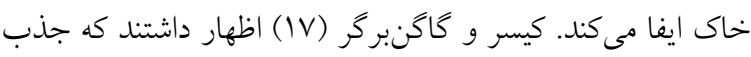

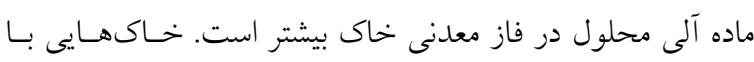

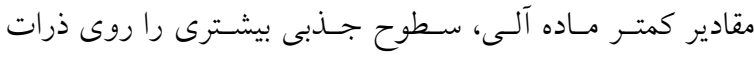

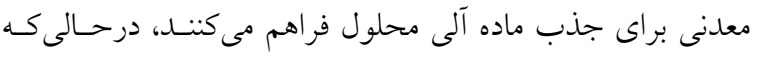




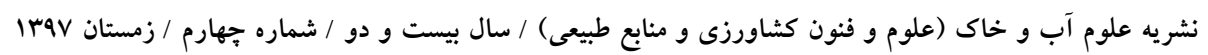

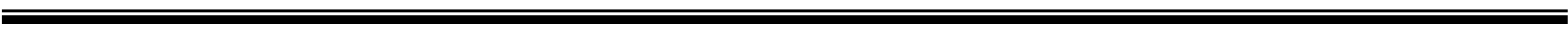

جدول r. ضرايب توزيع (Koc) و ضرايب توزيع كربن نرمال شده (K) جذب سيمازين در شش خاك

\begin{tabular}{|c|c|c|c|c|c|c|}
\hline 9 & 0 & r & r & r & 1 & شماره خاى \\
\hline $1 / N Q$ & $T / Y Y$ & $r / 4 r$ & TNG & $r / 90$ & $\varphi / \circ 4$ & ضريب توزيع (Kd) \\
\hline $909 / 91$ & $\Delta Y N / \Delta \circ$ & TrT/DD & YYO/VA & $r 40 / T 0$ & rrq/19 & ضريب كربن نرمال شده (Koc) \\
\hline
\end{tabular}

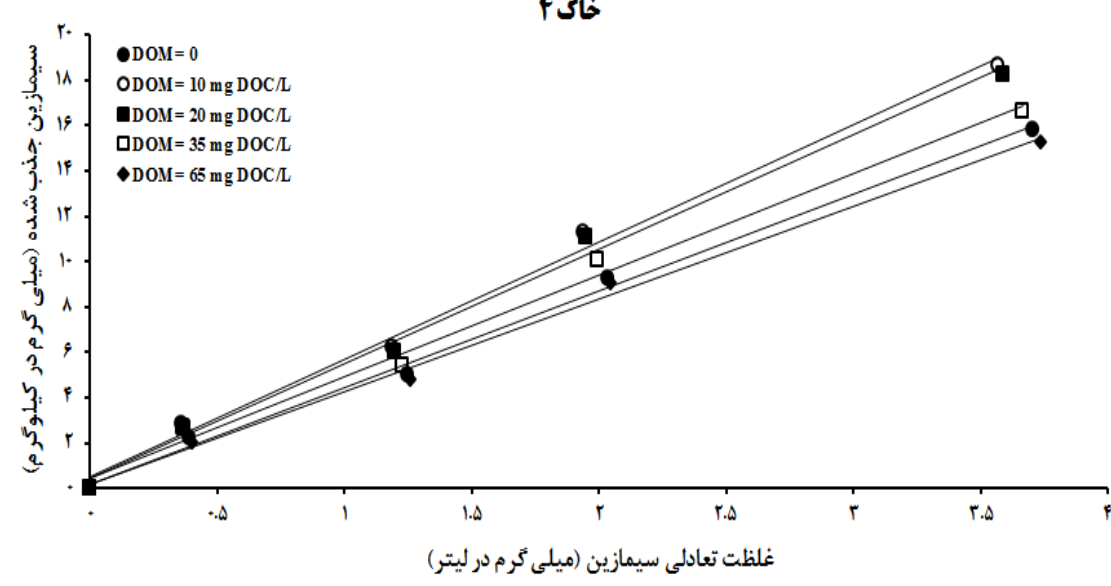

شكل f. همدماهاى خطى جذب سيمازين در خاك ثا در حضور ماده آلى محلول

اثرات ماده آلى محلول بر جذب سيمازين در خاكها در ايسـن آزمـايش يـك سيسـتم سـه فــازى (خــاك، محلـول و علفكش) براى بررسى توزيـع سـيمازين در حضـور مـاده آلى نى

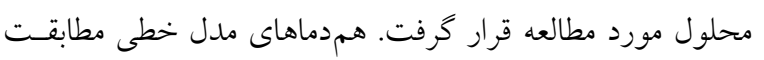
خوبى با نتايج جذبى سيمازين در خاكها داشت بهعنـوان نمونسه

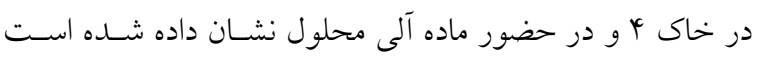

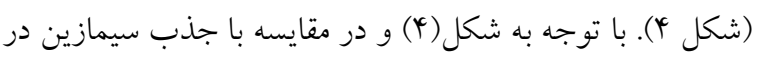
شرايط عدم حضور ماده آلى محلول، جذب سيمازين در حضـور •ا، هT و يا هـ ميلى گرم كربن آلى محلول در ليتر افزايش يافتـه، درحالى كه در تيمار ها9 ميلى گرم در ليتر ماده آلى محلول، جذب كاهش يافته است. لذا جذب سيمازين در خاكها به غلظت مـاده آلى محلول بستكى دارد. در اين آزمايش ضريب توزيــع ظـاهرى

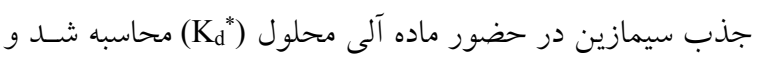

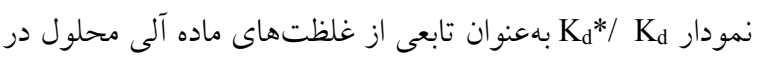
شكل (ه) نشان داده شده است. براى هر يكى از خاكهاى مـورد مطالعه، در ابتدا نسبت K K از مقدار يك تا مقـادير بيشـتر از

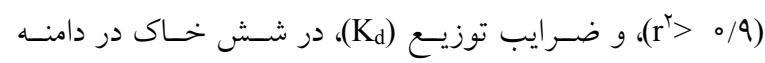

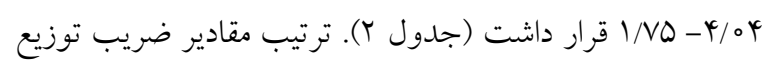
خاىهاى مورد مطالعه شامل خاى ا>> خاى ب> خاى ب> خاى ץ>> خاى ه>> خاى 9 است كه تقريباً همان ترتيـب مقـادير مـاده

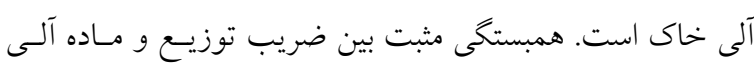
خاك نشان مى دهد كه ماده آلى خــاك نقـش مهمسى در توزيـع سيمازين روى خاكها دارد. ضرايب توزيع نرمال شده كربن آلى سلى (KOC) در شـش خـاك بـين 9/19 وس تـا 909/91 اسـت و بيشـترين و كمترين اين مقادير بهترتيب در خـاكهـاى و و ا مشـاهده شـد. همجنين تغييرات مقادير KOC توسـط اسـيارك و سـويفت (YV) كزارش شده و اظهار داشتند كه جذب آفت كشها روى خاكهــا نهتنها به مقدار كل ماده آلى خاك بستخى داشته بلكه در ارتباط با

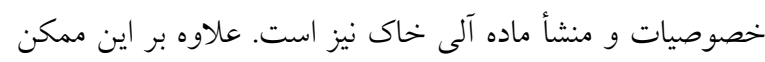
است خصوصيات فاز معدنى و شرايط محلول در زمان جذب در

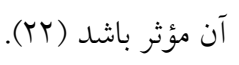




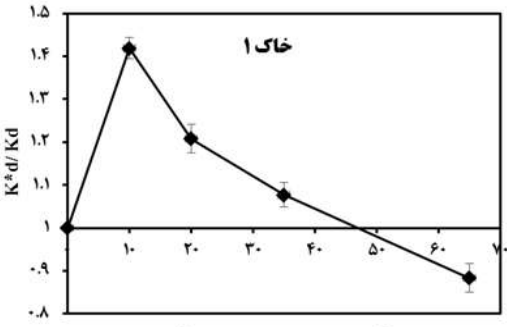

ماده آلى محلول (ميلى كرم كربن آلى در ليتر)

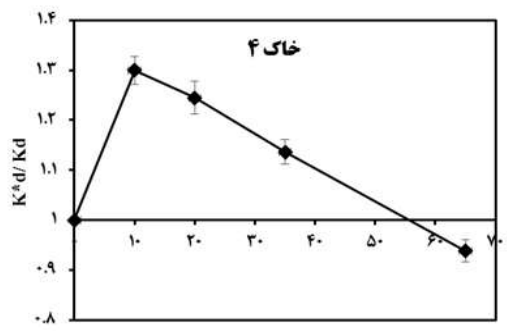

ماده آلى محلول (ميلى كرم كربن آلى در ليتر)

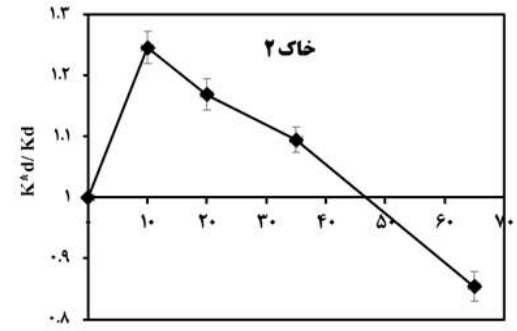

ماده آلى محلول (ميلى كرم كربن آلى در ليتر)

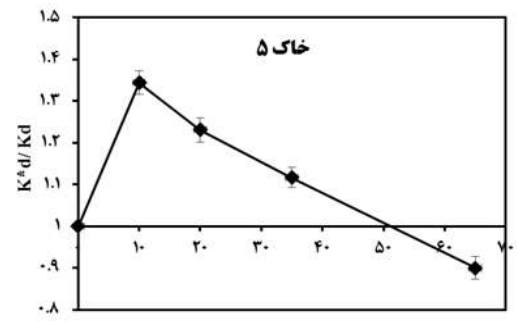

ماده آلى محلول (ميلى كرم كربن آلى در ليتر) ماده آلى محلول (ميلى كرم كربن آلى در ليتر)

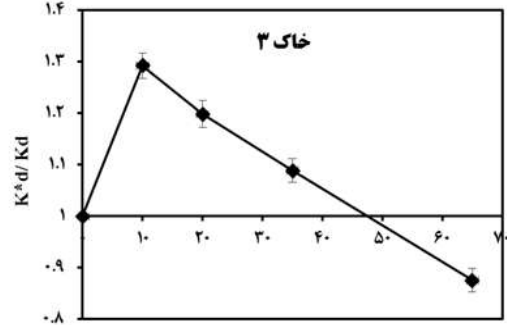

ماده آلى محلول (ميلى كرم كرين آلى در ليتر)

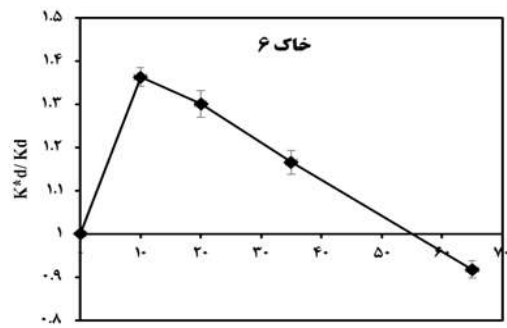

ماده آلى محلول (ميلى كرم كربن آلى در ليتر)

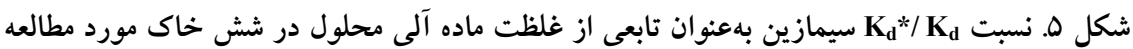

جدول r. حداكثر

\begin{tabular}{|c|c|c|c|c|c|c|}
\hline 4 & 0 & r & r & r & 1 & شماره خاى \\
\hline $1 / 44$ & $1 / \pi y$ & $1 / \mu \circ$ & $1 / 79$ & $1 / T \Delta$ & $1 / 4 T$ & حداكثر \\
\hline$\Delta \omega / \circ \Delta$ & $01 / 11$ & $\Delta Q / 9 \Delta$ & $\uparrow V / \uparrow q$ & $4 \varphi / \Lambda 1$ & $4 \varphi / 9 V$ & غلظت بحرانى ماده آلى محلول (DOMnp) (ميلى گرم كربن آلى در ليتر) \\
\hline
\end{tabular}

در خاكهايى با جذب بيشتر ماده آلى محلول، بهطور معنسدارى بيشتر است. همجينين نتايج نشان داد كه غلظت بحرانى مـاده آلى لى محلول با مقدار ماده آلى خاى همبستخى منفى دارد.

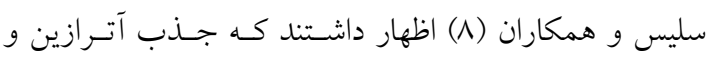

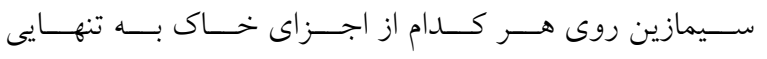
(مونتمرىلونيت، آهن آبدار و اسيد هيوميك) ارتباط مستقيمى به جذب آفت كشها در بيوندهاى دو يا جنــــايى بـا ايسن اجـزا خاى ندارد. تعداد و خصوصيات نقاط جذبى آفت كشها بهعلـت

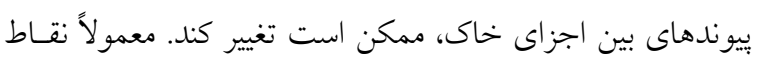
جذبى در ماده آلى اضافه شده به خاى براى جذب مولكولى لكولهـاى

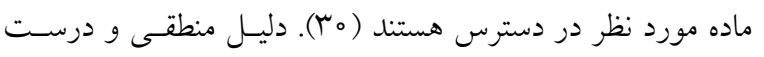
براى افزايش اوليه جذب سيمازين و بهدنبال آن كاهش جذب بـا افزايش غلظت مـاده آلى محلـول در سيسـتمهـاى آب-- خـاى
يك افزايش و با افزايش غلظت ماده آلى محلول ايسن نسـبت بـه مقادير كمتر از يك نيز كاهش يافت. لذا يك غلظت بحرانى براى

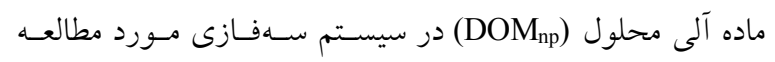
وجود داشت. در غلظت بـا برابر مىشود. درصورتى كه غلظت ماده آلى محلـول بـيش از غلظت بحرانى ماده آلى محلول شود، جذب سيمازين توسط ماده

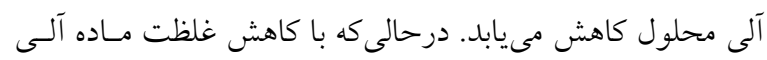

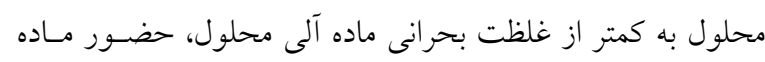
آلى محلول بهطور قابل ملاحظهاى جذب سيمازين در خاكها را افزايش مىدهد. مقادير غلظت ماده آلى محلول و حسـداكثر ميـزان

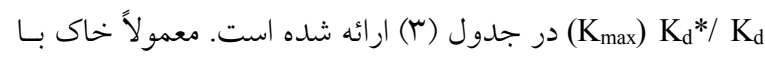

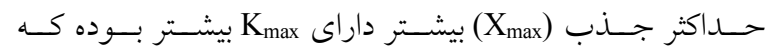
نشاندهنده اين است كه جذب سيمازين توسط ماده آلى محلـول 

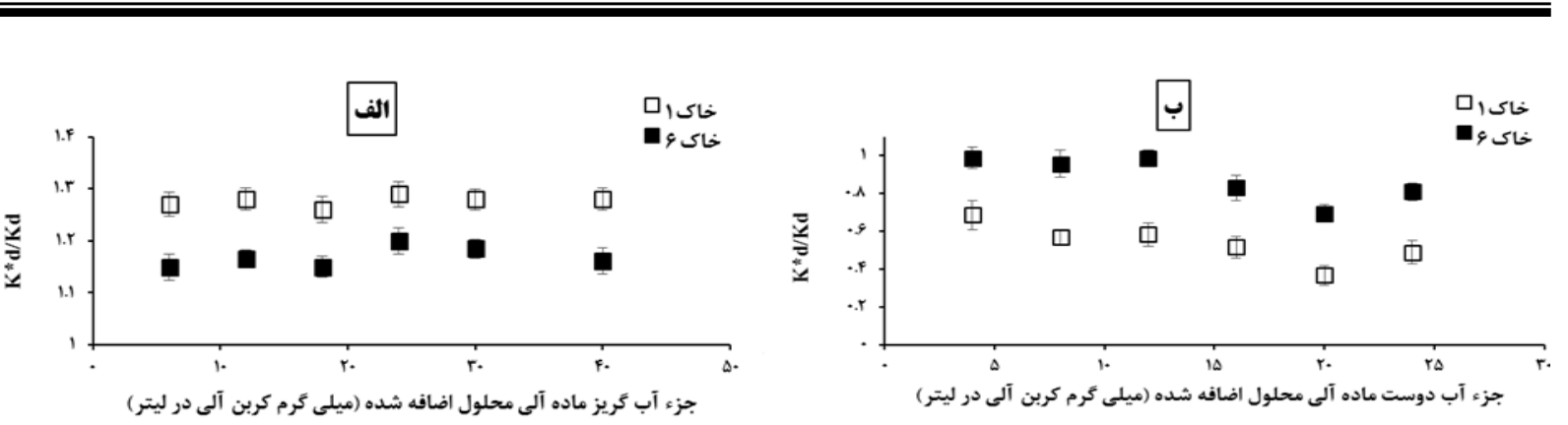
شكل 9. نسبت

آبَگريز ماده آلى محلـول در شكل 9 نشـان داده شــده اسـت.

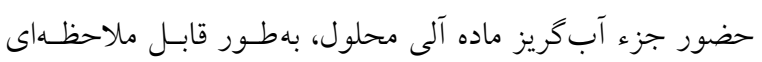

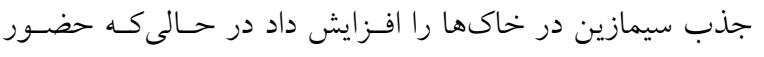

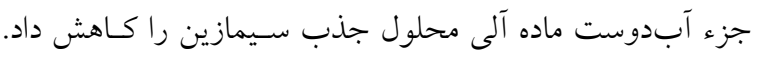

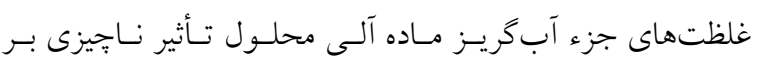

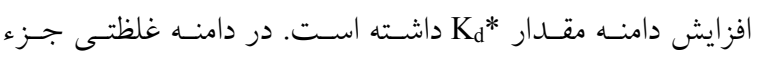

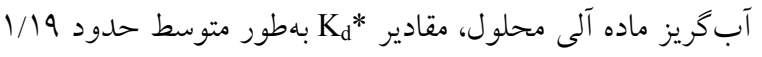

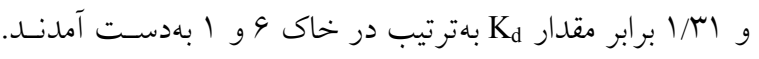

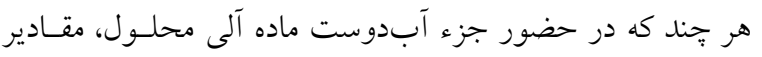

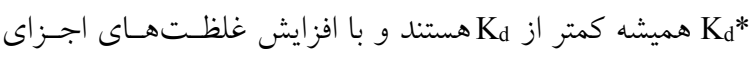

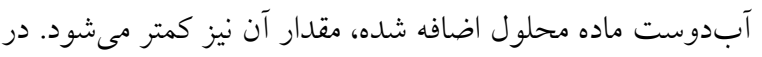

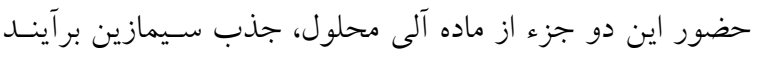

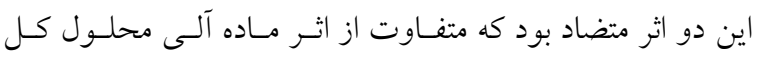

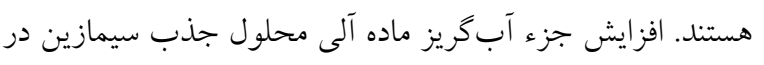

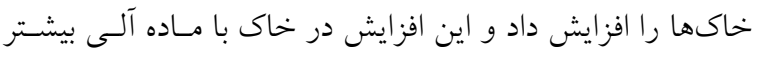

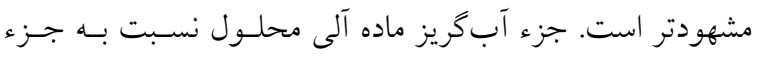

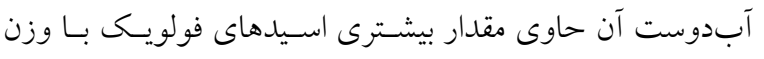

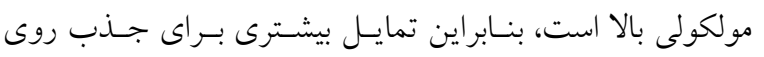

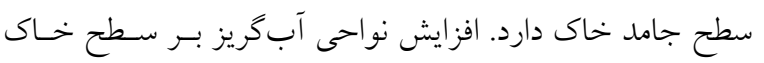

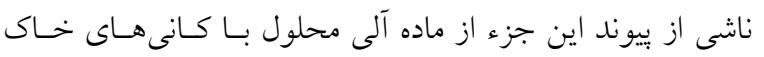

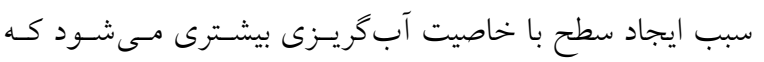

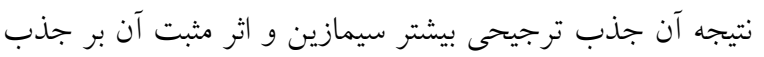

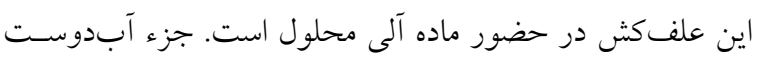

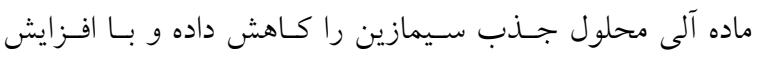

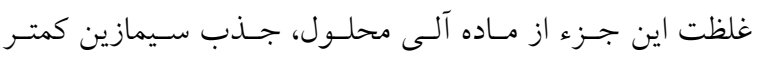

مى تواند شامل: الف) مقدار معينى از ماده آلى محلول روى سطح

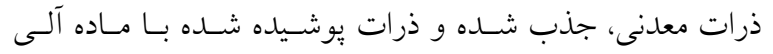

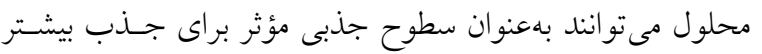

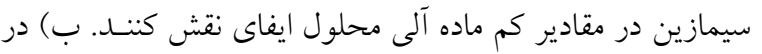

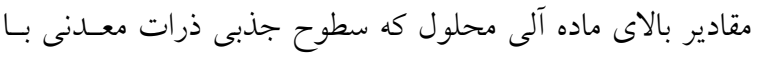

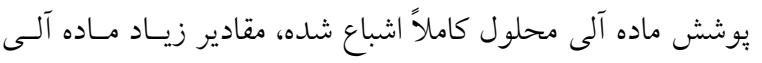

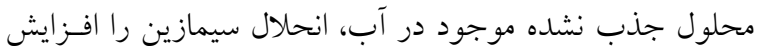

اثرات اجزاى آبدوست و آبگريز ماده آلى محلول بر جذب سيمازين در خاكها تركيبات با ساختارهاى شيميايى مختلف در محيط خـاك و مـاده

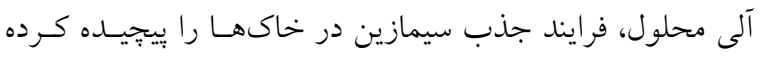

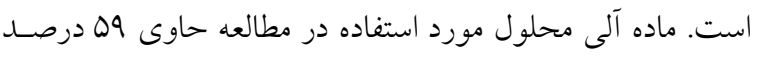

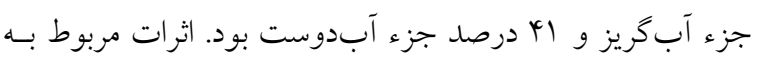

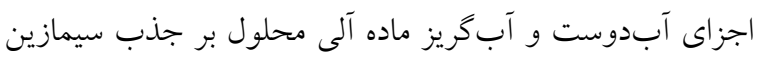

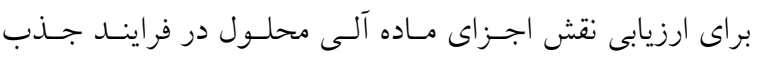

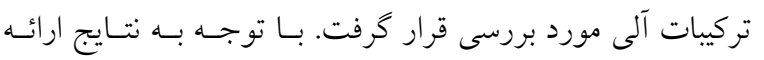
شده، خاك ال و خاك و بهترتيب داراى بالاترين و كمترين مقــدار

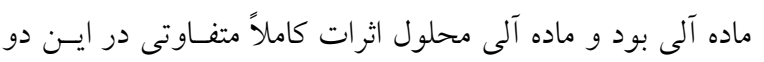

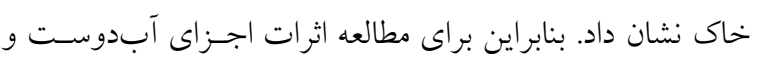
آبكريز ماده آلى محلول انتخاب شدند.

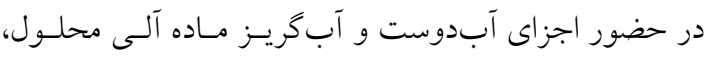

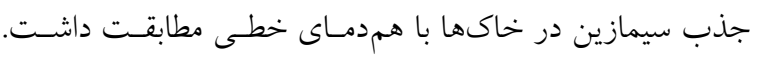

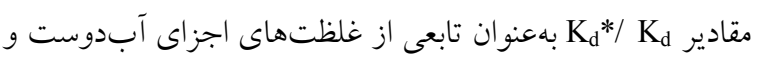


حضور ماده آلى محلول، بستخى به غلظت ماده آلى محلـول و ماده آلى خاى دارد. بهطوركلى جذب سيمازين در حضور مـاده آلى محلول با غلظت هاى كم، افزايش يافته است و بــرعكس در غلظتهاى بالاى ماده آلى محلول جذب كاهش مىيابد. مقـدار سيمازين در خاكها در ابتدا افزايش يافتـه و در ادامسه بـا افزايش غلظت ماده آلى محلول، كاهش مسىيابــ. غلظـتهــاى بحر انى ماده آلى محلول (DOMnp $)$ بـراى جــنب سـيمازين در حضور ماده آلى محلول بهدست آمد و در ايسن شــرايط مقـادير

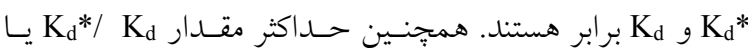

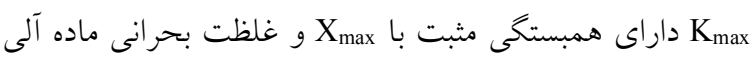
محلول داراى همبستخى منفى با مقدار ماده آلى خاكها اسـت. اثرات ماده آلى محلول بر جذب سيمازين را نمى توان با مقـادير ماده آلى جذب شده در خاك يا ماده آلى محلول موجود در فاز آبى تفسير كرد. بررسى بيشتر نشان داد كه حضور جزء آبكريز ماده آلى محلول سبب افزايش جذب سيمازين در خاكها شــده

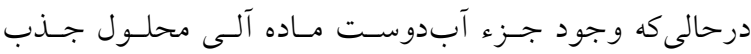
سيمازين را محدود كرد. برهمكنشهاى سطوح خـاك بـا مـاده آلى محلول و اجزاى آن فرايند اصلى در تعيين جذب سـيمازين در خاكها است. نتايج بهدست آمده در اين بيزوهش مسىتوانـد در درى بهتر اثـرات مـاده آلى محلـول در توزيـع آلاينـده در سيستم آب- خاى كمك كند. نتايج اين تحقيـق نشـان داد كـــ

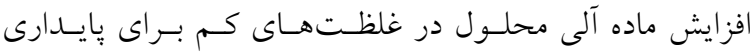
آفتكشهاى غيريونى در فاز جامــ مناسـب بـود و نتيجـهـ آن افزايش جذب اين تركيبات است. درحسالى كـه در غلظـتهـاى

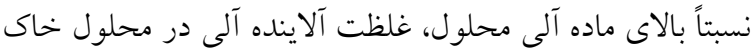
افزايش مىيابد و ممكن است قابليت اسـتفاده زيسـتى آن را در سيستم محلول خاى افزايش دهد.
مى شود. كاهش جذب سيمازين در اثر افزايش جـزء آبدوسـت ماده آلى محلول در ارتباط با: الف) بيوند اجزاى آبددوست مـاده آلى محلول با خاك، سطح كـانىهـا داراى خاصسيت آبدوسـتى بيشتر شده كه اين منجر به جذب ترجيحسى مولكـوهـاى آب بـهـ جاى تركيبات آلى آبكريز مى شود (r). ب) جذب رقـابتى بـين ماده آلى محلول و سـيمازين روى سـطح خـاك ج) رهـا شـدن

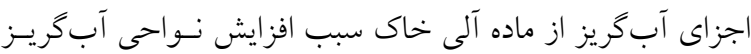
در فاز محلول شده (1) و اين باعث افزايش حلاليت سـيمازين مى شود. در خاكهايى با درصد ماده آلى بالا، رهاسازى ماده آلى لى

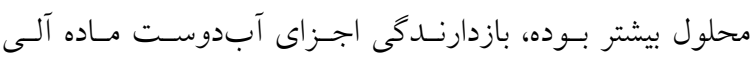
محلول بر جذب سيمازين مشهودتر مىشود. اثرات كل ماده آلى محلول بر جذب سيمازين بر اساس نتايج مشاهده شده از اين دو جزء ماده آلى محلول بيشنهاد شد و مقدار بهدست آمده براى ماده آلى محلول كل، نتيجه مجمـوع / K K مقدار اين نسبت در دو حالت اجزاى آبدوست و آبكريز مـاده آلى محلول است (شكل 9). ماده آلى محلول كل بهطور متوسـط

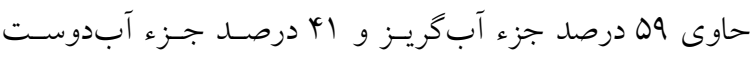
است. نتايج اين بررسى نشان داد كه جزء جـزءء كـــدن مـاده آلى لـ محلول براى تعيين خصوصيات ساختار شيميايى آن در تحقيقات رفتار محيطى ماده آلى محلول مورد نياز است.

\section{نتيجه گيرى}

جذب ماده آلى محلول در خاكها با مدل لانخمـوير مطابقت داشت. همبستخى منفى بين X جذب ماده آلى محلول روى جزء معدنى خاى بـهعلـت ايجـاد يوشش روى اجزاى معسدنى توسـط مـاده آلى خــاك، جـــب سيمازين نيز محدود مى شود. جذب سـيمازين در خـاكهـا در

\section{منابع مورد استفاده}

1. Aiken, G. R. and J. A. Leenheer. 1993. Isolation and chemical characterization of dissolved and colloidal organic matter. Journal of Chemical Ecology 8: 135-151.

2. Barriuso, E. and R. Calvet. 1992. Soil type and herbicides adsorption. International Journal of Environmental Analytical Chemistry 46: 117-128.

3. Barriuso, E., U. Baer and R. Caiver. 1992. Dissolved organic matter and adsorption-desorption of dimefuron, 
atrazine and carbetamide by soils. Journal of Environmental Quality 21: 359-367.

4. Barriuso, E. R. Calvet and S. Houot. 1985. Field study of the effect of sewage sludge application on atrazine behavior in soil. International Journal of Environmental Analytical Chemistry 59: 107-121.

5. Bouyoucos, C. J. 1962. Hydrometer method improved for making particle-size analysis of soil. Agronomy Journal 54: 464-465.

6. Celis, R., E. Barriuso and S. Houot. 1998. Sorption and desorption of atrazine by sludge-amend soil: Dissolved organic matter effects. Journal of Environmental Quality 27: 1348-1356.

7. Celis, R., E. Barriuso and S. Houot. 1998. Effect of liquid sewage addition on atrazine sorption and desorption by soil. Chemosphere 37(6): 1091-1107.

8. Celis, R., M. C. Hermosin and L. Cox. 1999. Sorption of 2, 4-dichlorophenoxyacelic acid by model soil particles simulating naturally occurring soil colloids. Environmental Science \& Technology 33: 1200-1206.

9. Chen G., C. Lin, L. Chen and H. Yang. 2011. Effect of polar-dissolved organic matter fractions on the mobility of prometryne in soil. Journal of Soils and Sediments 11: 395-405

10. Chiou, C. T., P. E. Porter and D. W. Schmedding. 1983. Partition equilibria of non-ionic organic compounds between soil organic matter and water. Environmental Science \& Technology 17: 227-231.

11. Cox, L., R. Celis and M. C. Hermosin. 2000. Effect of organic amendments on Herbicide sorption as related to the nature of the dissolved organic matter. Environmental Science \& Technology 34: 4600- 4605.

12. Cremlyn, R. J. 1990. Agrochemicals; Preparation and mode of action. John Wiley \& Sons Ltd. West Sussex, UK.

13. Gao, Y. Z. and L. Z. Zhu. 2003. Phytoremediation and its models for organic contaminated soils. Journal of Environmental Sciences 15: 302-310.

14. Garcia-Valcarcel, A. I., T. Matienzo, J. Sanchez-Brunete and J. L. Cand-Tadeo. 1998. Adsorption of triazines in soils with low organic matter content. Fresenius Environmental Bulletin 7: 649-656.

15. Herry, V. M. 2002. Association of hydrophobic organic contaminants with soluble organic matter: evaluation of the database of $\mathrm{K}_{\mathrm{doc}}$ values. Advances in Environmental Research 6: 577-593.

16. Hutson, D. H. and T. R. Roberts. 1990. Environmental Fate of Pesticides. John Wiley and Sons Ltd., Chi Chester.

17. Kaiser, K. and G. Guggenberger. 2000. The role of DOM sorption to mineral surfaces in the preservation of organic matter in soils. Organic Geochemistry 31: 711-725.

18. Kaiser, K. and W. Zech. 1998. Soil dissolved organic matter sorption as influenced by organic and sesquioxide coating and sorbed sulfate. Soil Science Society of America Journal 62: 129-136.

19. Kogel-Knabner, I., K. U. Totsche and B. Raber. 2000. Desorption of polycyclic aromatic hydrocarbons from soil in the presence of dissolved organic matter effect of solution, composition and aging. Environmental Science \& Technology 29: 906-916.

20. Kretzschmar, R., D. Hesterberg and H. Sticher. 1997. Effect of adsorbed humic acid on surface charge and flocculation of kaolinite. Soil Science Society of America Journal 61: 101-108.

21. Mathava, K. and P. Ligy. 2006. Adsorption and desorption characteristics of hydrophobic pesticide endosulfan in four Indian soils. Chemosphere 62: 1064-1077.

22. Murphy, M. E., J. M. Zachara and S. C. Smith. 1994. Interaction of hydrophobic organic compounds with mineralbound humic substances. Environmental Science \& Technology 28: 1291-1299.

23. Nelson, D. W. and L. E. Sommers. 1996. Total Carbon, Organic Carbon, and Organic Matter: Loss-on Ignition Method. P. 1004. In: D. L. Sparks, et al., (Eds.), Methods of Soil Analysis Part 3. $3^{\text {rd }}$ ed. American Society of Agronomy, Madison, WI.

24. Rigi, M. R., M. Farahbakhsh and K. Rezaei. 2015. Adsorption and desorption behavior of herbicide metribuzin in different soils of Iran. Journal of Agricultural Science and Technology 3(17): 777-787.

25. Seol, Y. and L. S. Lee. 2000. Effect of dissolved organic matter in treated effluents on sorption of atrazine and prometryn by soils. Soil Science Society of America Journal 64: 1976-1983.

26. Shen, Y. H. 1999. Sorption of natural dissolved organic matter on soil. Chemosphere 38(7): 1505-1515.

27. Spark, K. M. and R. S. Swift. 2002. Effect of soil composition and dissolved organic matter on pesticide sorption. Science of the Total Environment 298: 147-151.

28. Totsche, K. U., J. Danzer and I. Kogel-Knabner. 1997. Dissolved organic matter-enhanced retention of polycyclic aromatic hydrocarbons in soil miscible displacement experiments. Journal of Environmental Quality 26: 1090-1100.

29. Vencill, W. K. 2002. Herbicide Handbook, $8^{\text {th }}$ ed. Weed Science Society of America, Lawrence, KS.

30. Xing, B., J. J. Pignatello and B. Gigliotti. 1996. Competitive sorption between atrazine and other organic compounds in soils and model sorbents. Environmental Science \& Technology 30(8): 2432-2440. 


\title{
Effects of Dissolved Organic Matter on the Simazine Sorption in Different Soils
}

\author{
M. R. Rigi ${ }^{*}$ \\ (Received: January 2-2017 ; Accepted: January 27-2018)
}

\begin{abstract}
The effects of dissolved organic matter (DOM), derived from compost, on the sorption of simazine by soils were studied using a batch equilibrium technique. Six soils with different organic carbon contents were investigated in this study. Simazine sorption isotherms on soils were described by the linear equation, and the distribution coefficients without DOM $\left(\mathrm{K}_{\mathrm{d}}\right)$ or with DOM $\left(\mathrm{K}_{\mathrm{d}}{ }^{*}\right)$ were obtained. Generally, the values of $\mathrm{K}_{\mathrm{d}} * / \mathrm{K}_{\mathrm{d}}$ were initially increased and then decreased with raising DOM concentrations of $0-65 \mathrm{mg}$ DOC $\mathrm{L}$ in the soil-solution system form. Critical concentrations of DOM $\left(\mathrm{DOM}_{\mathrm{np}}\right)$ were obtained, and the value of $\mathrm{K}_{\mathrm{d}}{ }^{*}$ was equal to $\mathrm{K}_{\mathrm{d}}$. The presence of DOM with concentrations lower than $\mathrm{DOM}_{\mathrm{np}}$ promoted simazine sorption on the soils $\left(\mathrm{K}_{\mathrm{d}} *>\mathrm{K}_{\mathrm{d}}\right)$, whereas the presence of DOM with concentrations higher than $\mathrm{DOM}_{\mathrm{np}}$ tended to inhibit the simazine sorption $\left(\mathrm{K}_{\mathrm{d}} *<\mathrm{K}_{\mathrm{d}}\right)$. Interestingly, DOM $\mathrm{In}_{\mathrm{np}}$ for the tested soils was negatively correlated to the soil organic carbon content, and the maximum of $\mathrm{K}_{d} * / \mathrm{K}_{\mathrm{d}}\left(\mathrm{K}_{\max }\right)$ was correlated positively with the maximum of DOM sorption on the soil $\left(\mathrm{X}_{\max }\right)$. Further investigations also showed that the presence of the hydrophobic fraction of DOM evidently promoted the simazine sorption on soils, whereas the presence of hydrophilic DOM fraction obviously tended to inhibit the simazine sorption.
\end{abstract}

Keywords: Pesticide, Simazine, Dissolved Organic Matter, Sorption, Soil

1. Department of Plant Productions, Faculty of Agriculture, Higher Educational Complex of Saravan, Sravan, Iran.

*: Corresponding Author, Email: rezarigi@gmail.com 